\title{
ANALISIS PERHITUNGAN JEMBATAN GELAGAR I PADA JEMBATAN JALAN RAYA DAN JEMBATAN KERETA API
}

\author{
Irpan Hidayat \\ Civil Engineering Department, Faculty of Engineering, Binus University \\ Jl. K.H. Syahdan No. 9, Palmerah, Jakarta Barat 11480 \\ irpan@binus.edu
}

\begin{abstract}
The bridge is a means of connecting roads which is disconnected by barriers of the river, valley, sea, road or railway. Classified by functionality, bridges can be divided into highway bridge and railroad bridge. This study discusses whether the use of I-girder with $210 \mathrm{~m}$ height can be used on highway bridges and railway bridges. A comparison is done on the analysis of bridge structure calculation of $50 \mathrm{~m}$ spans and loads used in both the function of the bridge. For highway bridge, loads are grouped into three, which are self weight girder, additional dead load and live load. The additional dead loads for highway bridge are plate, deck slab, asphalt, and the diaphragm, while for the live load is load D which consists of a Uniform Distributed Load (UDL) and Knife Edge Load (KEL) based on "Pembebanan Untuk Jembatan RSNI T-02-2005". The load grouping for railway bridge equals to highway bridge. The analysis on the railway bridges does not use asphalt, and is replaced with a load of ballast on the track and the additional dead load. Live load on the structure of the railway bridge is the load based on Rencana Muatan 1921 (RM.1921). From the calculation of the I-girder bridge spans $50 \mathrm{~m}$ and girder height $210 \mathrm{~cm}$ for railway bridge, the stress on the lower beam is over the limit stress allowed. These results identified that the I-girder height $210 \mathrm{~cm}$ at the railway bridge has not been able to resist the loads on the railway bridge.
\end{abstract}

Keywords: bridges, roads, railways, load

\begin{abstract}
ABSTRAK
Jembatan merupakan sarana penghubung jalan yang terputus karena rintangan sungai, lembah, laut, jalan maupun rel kereta api. Jika diklasifikasikan secara fungsinya jembatan dapat dibedakan menjadi jembatan jalan raya dan jembatan kereta api. Pada paper ini, akan diperlihatkan apakah penggunaan gelagar I dengan tinggi $210 \mathrm{~m}$ dapat dipergunakan pada jembatan jalan raya maupun jembatan kereta api. Perbandingan dilakukan pada analisis perhitungan struktur jembatan dengan bentang $50 \mathrm{~m}$ dan beban-beban yang digunakan pada kedua fungsi jembatan tersebut. Untuk jembatan jalan raya beban dikelompokkan menjadi tiga kelompok beban, yaitu berat sendiri gelagar, beban mati tambahan, dan beban hidup. Beban mati tambahan yang dianalisis yaitu beban pelat, deck slab, aspal, dan diafragma sedangkan untuk beban hidup dengan fungsi jalan raya adalah beban D yang terdiri dari beban terdistribusi (load distribution) dan beban Knife Edge Load (KEL) berdasarkan "Pembebanan Untuk Jembatan RSNI T-02-2005". Pengelompokkan beban untuk jembatan kereta api sama dengan jembatan jalan raya. Yang membedakan dalam analisis perhitungan yaitu tidak adanya beban aspal pada jembatan kereta api dan digantikan dengan beban track dan ballast pada beban mati tambahan. Beban hidup yang bekerja pada struktur atas jembatan kereta api adalah beban yang berasal dari rangkaian kereta api yang besarnya ditentukan berdasarkan Rencana Muatan 1921 (RM.1921). Dari hasil perhitungan antara jembatan gelagar I bentang $50 \mathrm{~m}$ untuk jembatan jalan raya dan jembatan kereta api untuk tinggi gelagar $210 \mathrm{~cm}$ diperoleh kesimpulan untuk tinggi gelagar $210 \mathrm{~cm}$ pada jembatan kereta api, tegangan pada serat bawah tidak mencukupi batas tegangan yang diijinkan. Dari hasil ini dapat diidentifikasikan bahwa tinggi gelagar $210 \mathrm{~cm}$ pada jembatan kereta api belum mampu menahan beban yang ada pada jembatan kereta api.
\end{abstract}

Kata kunci: beban, jembatan, jalan raya, kereta api 


\section{PENDAHULUAN}

Jembatan merupakan bagian dari jalan yang menghubungkan jalan yang terputus karena rintangan seperti sungai, lembah, laut, jalan maupun rel kereta api. Pada paper ini, akan diperlihatkan analisis perhitungan jembatan gelagar I bentang $50 \mathrm{~m}$ untuk jembatan kereta api dan jembatan jalan raya. Beban-beban yang diperhitungkan adalah beban yang digunakan sesuai dengan fungsi jembatan pada jembatan jalan raya dan jembatan kereta api. Untuk jembatan jalan raya beban dikelompokkan menjadi 3 kelompok beban yaitu berat sendiri gelagar, beban mati tambahan, dan beban hidup. Untuk beban mati tambahan yang di analisis yaitu beban pelat, deck slab, aspal, dan diafragma sedangkan untuk beban hidup dengan fungsi jalan raya adalah beban $\mathrm{D}$ yang terdiri dari beban terdistribusi (load distribution) dan beban Knife Edge Load (KEL) berdasarkan "Pembebanan Untuk Jembatan RSNI T02-2005".

Pengelompokkan beban untuk jembatan kereta api sama dengan jembatan jalan raya. Yang membedakan dalam analisis perhitungan yaitu tidak adanya beban aspal pada jembatan kereta api dan digantikan dengan beban track dan ballast pada beban mati tambahan. Beban hidup yang bekerja pada struktur atas jembatan kereta api adalah beban yang berasal dari rangkaian kereta api yang besarnya ditentukan berdasarkan Rencana Muatan 1921 (RM.1921).

Analisis perhitungan kedua jenis jembatan (jalan raya dan kereta api) menggunakan panjang gelagar, jarak antar gelagar, penampang gelagar, tebal pelat, dan tebal deck slab yang sama. Kuat tekan beton untuk gelagar adalah $724,3 \mathrm{~kg} / \mathrm{cm}^{2}$ (K-800) sedangkan untuk pelat $291,8 \mathrm{~kg} / \mathrm{cm}^{2}(\mathrm{~K}-350)$. Kabel prategang yang digunakan yaitu uncoated stress relieve 7 wires strand dengan kuat tarik ultimate: $19.000 \mathrm{~kg} / \mathrm{cm}^{2}$, diameter: $12,7 \mathrm{~mm}$, luas efektif: $0,987 \mathrm{~cm}^{2}$, dan modulus elastisitas $1.960 .000 \mathrm{~kg} / \mathrm{cm}^{2}$.

Adapun tujuan penulisan ini adalah sebagai berikut: (1) menganalisis kekuatan profil I terhadap gaya-gaya yang bekerja khususnya beban hidup pada jalan raya dan kereta api; (2) menghitung kekuatan gelagar I jembatan jalan raya dan jembatan kereta api pada kondisi awal (setelah diberi gaya prategang) dan kondisi layan; (3) mengetahui apakah dimensi penampang gelagar I untuk jembatan jalan raya dapat juga dipergunakan untuk jembatan kereta api.

\section{METODE}

Metode penelitian yang dikembang dalam penelitian ini dapat dijelaskan seperti gambar diagram alir di bawah ini (Gambar 1).

\section{Metode Perhitungan}

Konsep beton prategang sendiri adalah pemberian gaya prategang atau tegangan kepada kabel prategang yang diaplikasikan dalam beton. Pemberian gaya prategang dapat dilakukan sebelum atau sesudah beton dicor. Pemberian prategang sebelum dilakukan pengecoran disebut juga pratarik (pretensioned), sedangkan pemberian prategang setelah dilakukan pengecoran disebut sistem pascatarik (post-tensioned).

Pemberian gaya prategang pada beton akan memberikan tegangan tekan pada penampang. Tegangan ini akan menahan beban luar yang bekerja pada penampang. Posisi penegangan dapat memberikan keuntungan yang lebih apabila diatur secara tepat. Apabila gaya prategang yang bekerja tidak terletak di pusat penampang melainkan dengan eksentrisitas, maka tegangan akan bertambah 
akibat eksentrisitas tersebut. Beton prategang dapat mengalami gaya prategang penuh (fully prestressed) ataupun gaya prategang sebagian (partial prestressed). Prategang penuh adalah penampang struktur tidak diizinkan ada tegangan tarik pada penampang baik pada tahap transfer sampai dengan masa layan dan tegangan pada serat bawah dianggap tidak ada. Sedangkan prategang sebagian adalah penampang struktur direncanakan untuk dapat menerima tegangan tarik pada lokasi penampang selama masa transfer sampai masa layan dan tegangan serat bawah beton tidak sama dengan nol.

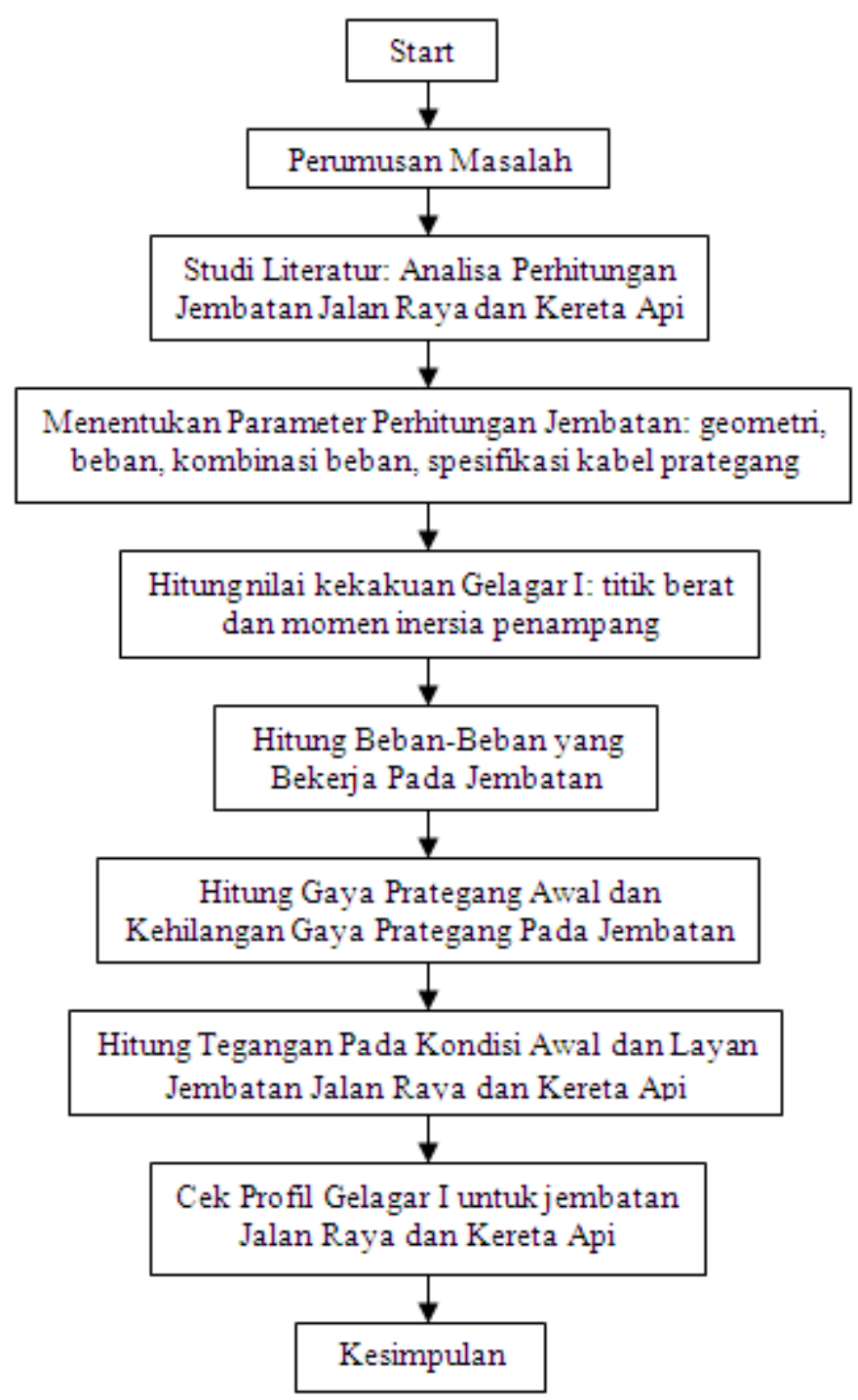

Gambar 1 Bagan alir penelitian.

Metode penentuan gaya prategang ada dua macam, yaitu metode elastis dan metode Magnel's. Metode elastis adalah metode yang paling sering digunakan karena lebih baik dalam perhitungan apabila tegangan tarik terjadi pada masa layan dan mengalami keretakan yang wajar, atau apabila tegangan tekan berlebih dan perpendekan jangka panjang yang besar dapat diperkirakan.

Metode elastis juga berguna untuk memperkirakan kemungkinan masalah pada daya layan. Berikut ini adalah diagram tegangan untuk metode elastic (Gambar 2): 


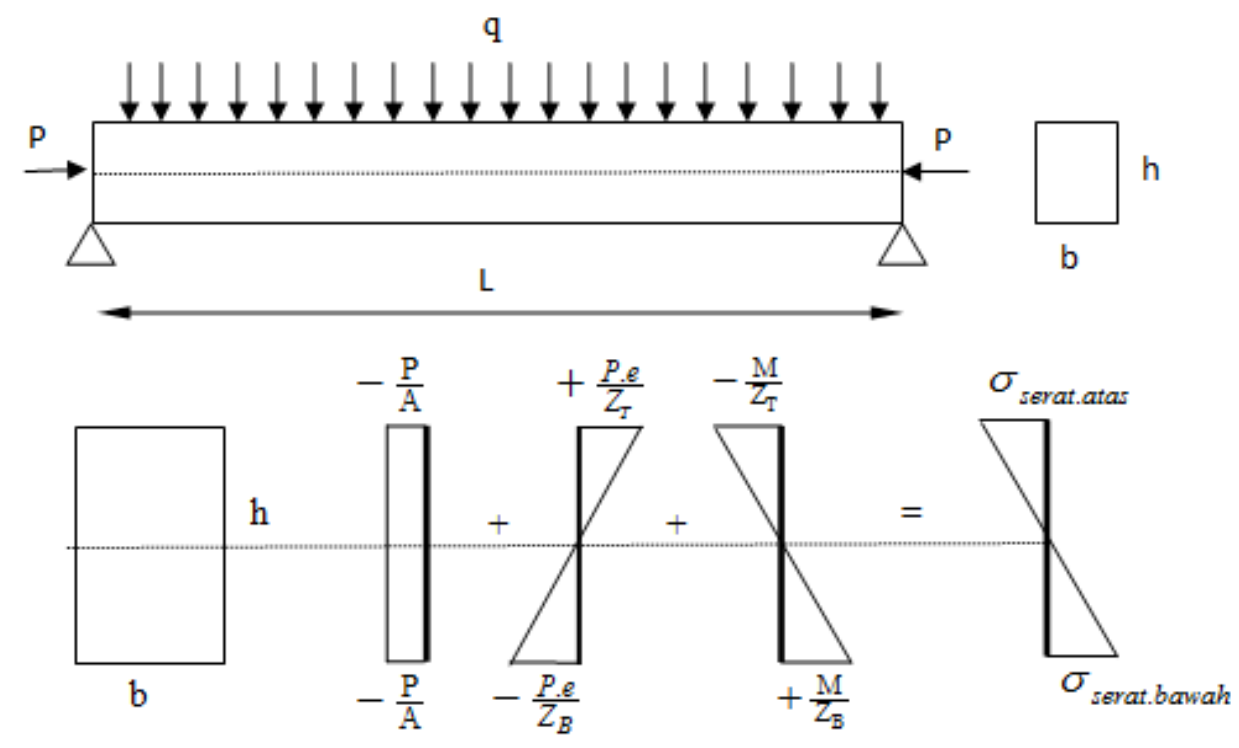

Gambar 2 Diagram tegangan.

Dari diagram tegangan diatas dapat disimpulkan resultan tegangan di serat atas maupun serat bawah adalah sebagai berikut:

$$
\begin{gathered}
\sigma_{\text {serat.atas }}=-\frac{P}{A}+\frac{P . e}{Z_{T}}-\frac{M}{Z_{T}} . \\
\sigma_{\text {serat.bawah }}=-\frac{P}{A}-\frac{P . e}{Z_{T}}+\frac{M}{Z_{T}}
\end{gathered}
$$

di mana:

$\sigma_{\text {serat.atas }}=$ tegangan pada serat atas beton

$\sigma_{\text {serat.bawah }}=$ tegangan pada serat bawah beton

$P \quad=$ gaya prategang

A $\quad=$ luas penampang beton

e $\quad=$ eksentrisitas

$Z_{T} \quad=$ modulus penampang serat atas beton

$Z_{B} \quad=$ modulus penampang serat bawah beton

$M \quad=$ momen yang terjadi

Beton prategang mengalami beberapa tahap pembebanan. Setiap pembebanan, beton prategang harus dilakukan pengecekan saat kondisi serat tertekan maupun saat tertarik. Tahap pembebanan pada beton prategang adalah: (1) masa peralihan (transfer); (2) masa layan (service). Dengan batas ijin tegangan untuk masa peralihan dan masa layan sesuai dengan RSNI 2004 Perencanaan Struktur Beton Untuk Jembatan adalah sebagai berikut

Masa peralihan:

$$
\begin{array}{ll}
\text { Serat Tertekan } & =0.6 f^{\prime} c i \\
\text { Serat Tertarik } & =0.25 \sqrt{f^{\prime} c l}
\end{array}
$$


Masa Layan:

$$
\begin{array}{ll}
\text { Serat Tertekan } & =0.45 f^{\prime} c \\
\text { Serat Tertarik } & =0.5 \sqrt{f^{\prime} c} \\
\text { Dengan } f^{\prime} c i & =0.7 f^{\prime} c
\end{array}
$$

Kabel baja prategang akan mengalami kehilangan saat di mana gaya prategang mengalami kehilangan gaya pada setiap pembebanan yang dilakukan hingga menjadi gaya prategang efektif pada saat akhir yaitu masa layan. Kehilangan gaya sesaat (immediate losses) dialami oleh gaya prategang saat masa peralihan berlangsung. Kehilangan gaya sesaat disebabkan oleh perpendekan elastis pada beton maupun tendon, gesekan yang terjadi pada kabel dan gesekan pada angkur. Sedangkan kehilangan gaya pada masa layan disebut kehilangan gaya jangka panjang (time-dependent losses). Kehilangan gaya ini disebabkan oleh susut dan rangkak pada beton dan relaksasi pada baja. Berikut ini adalah bagan kehilangan gaya dalam prategang (Gambar 3).

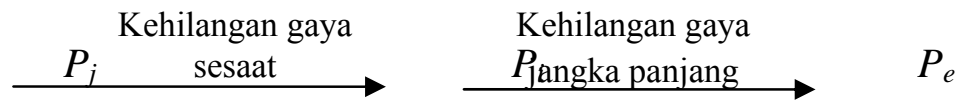

Gambar 3 Bagan Kehilangan Gaya Prategang.

di mana:

$P_{j} \quad$ = gaya prategang pada jack saat sebelum masa peralihan

$P_{i} \quad$ = gaya prategang awal setelah masa peralihan

$P_{e} \quad=$ gaya prategang efektif setelah kehilangan gaya jangka panjang

\section{HASIL DAN PEMBAHASAN}

\section{Geometri Struktur Jembatan}

Geometri struktur jembatan kereta api dan jalan raya untuk analisis perhitungan adalah sama. Dengan data geometri struktur jembatan arah longitudinal adalah $50 \mathrm{~m}$ dengan lebar arah transversal nya yaitu $5 \mathrm{~m}$. Segmentasi gelagar arah longitudinal jembatan dibagi menjadi 7 segmen dengan masing-masing panjang segmen secara berurutan adalah sebagai berikut 6,6-7-7-8,8-7-7-6,6 m. Jumlah gelagar I arah tranversal sebanyak 3 buah dengan jarak antar gelagar 1,4 $\mathrm{m}$ dan tambahan panjang pada ujung gelagar sebelah kiri dan kanan adalah $0,4 \mathrm{~m}$. Berikut ini adalah gambar struktur jembatan arah transversal dan longitudinal jembatan jalan raya dan kereta api (Gambar 4).

\section{Spesifikasi Teknis Material Jembatan}

Spesifikasi teknis gelagar dan kabel prategang beserta susunan konfigurasi tendon kabel prategang seperti penjelasan Tabel 1 dan 2 di bawah ini.

\section{Beban-Beban yang Bekerja}

Beban-beban yang bekerja pada jembatan jalan raya dan jembatan kereta api seperti diperlihatkan pada Tabel 3 di bawah ini. 

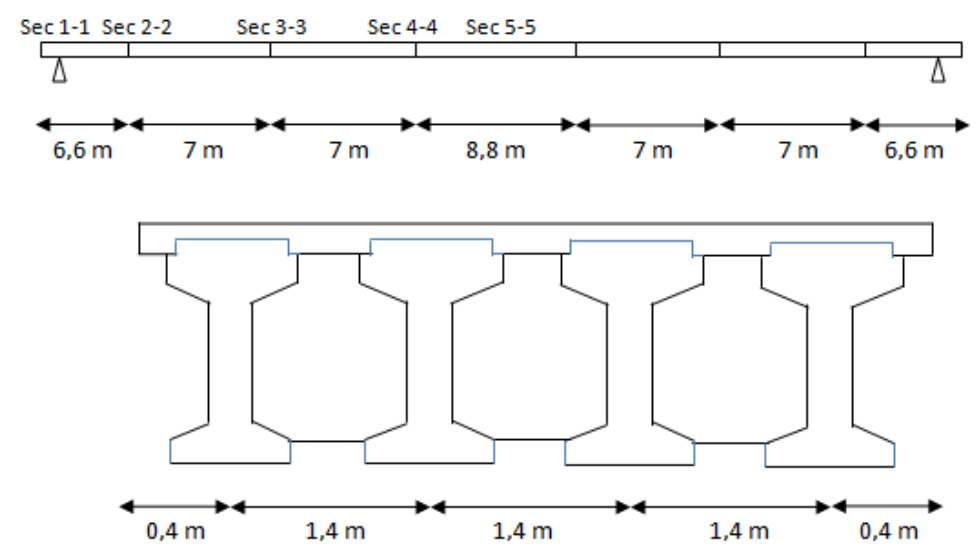

Gambar 4 Geometri struktur jembatan.

Tabel 1 Spesifikasi Teknis Gelagar I dan Kabel Prategang

\begin{tabular}{lrlr}
\hline \multicolumn{1}{c}{ Gelagar I } & \multicolumn{2}{c}{ Kabel Prategang } \\
Bentang & $50 \mathrm{~m}$ & Nominal diameter & $12,7 \mathrm{~mm}$ \\
\hline Tinggi Gelagar & $230 \mathrm{~cm}$ & Nominal area & $0,987 \mathrm{~cm}^{2}$ \\
\hline Jarak antar gelagar & $100 \mathrm{~cm}$ & Modulus of elastisity & $\mathrm{kg} / \mathrm{cm}^{2}$ \\
\hline Tebal pelat & $20 \mathrm{~cm}$ & Ultimate tensile strength & $19000 \mathrm{~kg} / \mathrm{cm}^{2}$ \\
\hline Kuat tekan gelagar & K -800 & Low-Relaxation. & \\
\hline Kuat tekan pelat & K -350 & Jumlah kabel prategang & 88 strand \\
\hline
\end{tabular}

Tabel 2 Susunan Konfigurasi Tendon

\begin{tabular}{cccc}
\hline \multirow{2}{*}{$\begin{array}{c}\text { No. } \\
\text { Tendon }\end{array}$} & Jumlah strand & \multicolumn{2}{c}{ Tinggi strand dari bawah (cm) } \\
\cline { 3 - 4 } & 12 & Tepi & Tengah \\
\hline 1 & 19 & 155 & 40 \\
\hline 2 & 19 & 125 & 25 \\
\hline 3 & 19 & 60 & 12,5 \\
\hline 4 & 19 & 30 & 12,5 \\
\hline 5 & & & 12,5 \\
\hline
\end{tabular}

Tabel 3 Beban-Beban yang Bekerja

\begin{tabular}{|c|c|c|c|c|}
\hline \multirow{2}{*}{$\begin{array}{c}\text { Komponen } \\
\text { Beban }\end{array}$} & \multicolumn{4}{|c|}{ Fungsi Jembatan } \\
\hline & Jalan Raya & Nilai Beban/m & Kereta Api & Nilai Beban/m \\
\hline \multirow{4}{*}{ Beban Mati } & Berat gelagar & 1,981 ton $/ \mathrm{m}$ & Berat gelagar & 1,981 ton $/ \mathrm{m}$ \\
\hline & Pelat & 0,5 ton $/ \mathrm{m}$ & Pelat & 0,5 ton $/ \mathrm{m}$ \\
\hline & Aspal & 0,154 ton $/ \mathrm{m}$ & Track + Balast & $9,0625 \mathrm{kN} / \mathrm{m}$ \\
\hline & Diafragma & 0,08177 ton $/ \mathrm{m}$ & Diafragma & 0,08177 ton $/ \mathrm{m}$ \\
\hline \multirow{2}{*}{ Beban Hidup } & Distribution Load & 0,720 ton $/ \mathrm{m}$ & \multirow{2}{*}{$\begin{array}{l}\text { Rencana Muatan } \\
\text { (RM 1921) }\end{array}$} & \multirow{2}{*}{120 kN/gandar } \\
\hline & Line Load & 9,604 ton & & \\
\hline
\end{tabular}




\section{Perhitungan Momen Inersia Penampang Gelagar I}

Nilai momen inersia dan modulus penampang gelagar I dibagi menjadi 2 bagian yaitu gelagar I precast dan gelagar I komposit. Gambar dan nilai momen inersia masing-masing gelagar diperlihatkan pada Gambar 5 dan Tabel 4 di bawah ini.

Tabel 4 Nilai Modulus Penampang Gelagar I Precast dan Komposit

\begin{tabular}{lrrrrrr}
\multicolumn{1}{c}{ Deskripsi } & Area $\left(\mathbf{c m}^{2}\right)$ & \multicolumn{1}{c}{ Ya $(\mathbf{c m})$} & Yb $(\mathbf{c m})$ & $\mathbf{I x}\left(\mathbf{c m}^{\mathbf{4}}\right)$ & $\mathbf{W a}\left(\mathbf{c m}^{3}\right)$ & $\mathbf{W b}\left(\mathbf{c m}^{3}\right)$ \\
\hline Precast Beam & 7523 & 108,805 & 101,195 & 41398803 & 380486,4 & 409099,1 \\
\hline Composite Beam & 9301 & 106,0939 & 123,9061 & 61756491 & 582092,6 & 498413,8 \\
\hline
\end{tabular}

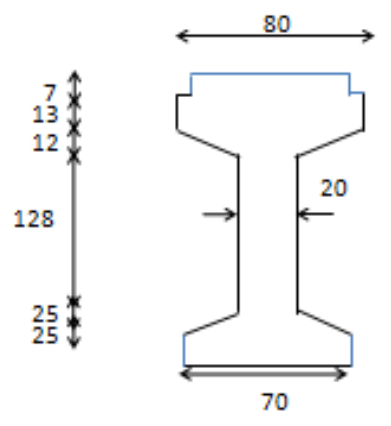

(a)
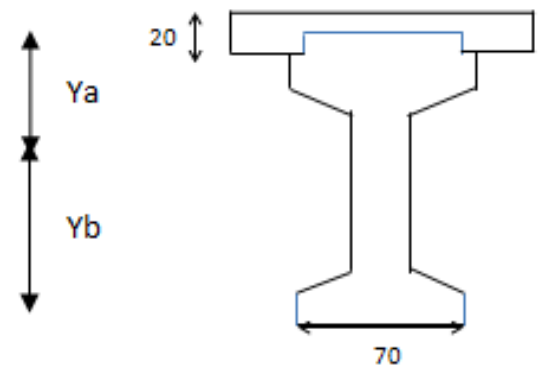

(b)

Gambar 5 Potongan Gelagar I Precast (a) dan Gelagar I Komposit

(b) (satuan dalam $\mathrm{cm}$ ).

Keterangan:

$\mathrm{Ya} \quad=$ jarak dari tepi atas gelagar ke titik berat penampang

$\mathrm{Yb} \quad=$ jarak dari tepi bawah gelagar ke titik berat penampang

Ix = nilai momen inersia penampang

Wa $=$ modulus penampang serat atas

$\mathrm{Wb}=$ modulus penampang serat bawah

\section{Perhitungan Gaya-Gaya dalam (Internal Forces)}

Perhitungan gaya-gaya dalam untuk jembatan fungsi jalan raya dan kereta api seperti diperlihatkan pada Tabel $5-8$ di bawah ini.

Tabel 5 Nilai Gaya dalam Momen Jembatan Jalan Raya (dalam ton)

\begin{tabular}{|c|c|c|c|c|c|c|}
\hline \multirow{2}{*}{ Tipe } & \multirow{2}{*}{ Beban } & Sec 1-1 & Sec 2-2 & Sec 3-3 & Sec 4-4 & Sec 5-5 \\
\hline & & $\mathbf{0 ~ m}$ & $6,6 \mathrm{~m}$ & $13,6 \mathrm{~m}$ & $20,6 \mathrm{~m}$ & $25 \mathrm{~m}$ \\
\hline DL & balok pracetak & 0 & 269,36 & 465,52 & 569,53 & 587,73 \\
\hline DL & Slab & 0 & 71,61 & 123,76 & 151,41 & 156,25 \\
\hline $\mathrm{ADL}$ & Lapis Aspal & 0 & 22,06 & 38,12 & 46,63 & 48,13 \\
\hline DL & diafragma + deck slab & 0 & 30,51 & 52,73 & 64,51 & 66,57 \\
\hline LL & Distribution Load & 0 & 144,37 & 249,50 & 305,24 & 315,00 \\
\hline & KEL & 0 & 55,02 & 95,09 & 116,33 & 120,05 \\
\hline Total & $\mathrm{DL}+\mathrm{LL})$ & 0 & 592,92 & 1024,71 & 1253,65 & 1293,73 \\
\hline
\end{tabular}


Tabel 6 Nilai Gaya dalam Geser Jembatan Jalan Raya (dalam ton)

\begin{tabular}{llrrrrc}
\hline \multirow{2}{*}{ Tipe } & \multirow{2}{*}{ Beban } & Sec 1-1 & Sec 2-2 & Sec 3-3 & Sec 4-4 & Sec 5-5 \\
\cline { 3 - 7 } & & $\mathbf{0 ~} \mathbf{~}$ & $\mathbf{6 , 6} \mathbf{~ m}$ & $\mathbf{1 3 , 6} \mathbf{~ m}$ & $\mathbf{2 0 , 6} \mathbf{~ m}$ & $\mathbf{2 5 ~} \mathbf{~}$ \\
\hline DL & balok pracetak & 47,02 & 34,61 & 21,44 & 8,28 & 0 \\
\hline DL & Slab & 12,50 & 9,20 & 5,70 & 2,20 & 0 \\
\hline ADL & Lapis Aspal & 3,85 & 2,83 & 1,76 & 0,68 & 0 \\
\hline DL & diafragma + deck slab & 5,33 & 3,92 & 2,43 & 0,94 & 0 \\
\hline LL & Distribution Load & 25,20 & 18,55 & 11,49 & 4,44 & 0 \\
\hline \multicolumn{2}{l}{ KEL } & 9,60 & 8,34 & 6,99 & 5,65 & 4,80 \\
\hline \multicolumn{2}{l}{ Total (DL+LL) } & 103,50 & 77,44 & 49,81 & 22,17 & 4,80 \\
\hline
\end{tabular}

Tabel 7 Nilai Gaya dalam Momen Jembatan Kereta Api (dalam ton)

\begin{tabular}{llcrrrr}
\hline \multirow{2}{*}{ Tipe } & \multirow{2}{*}{ Beban } & Sec 1-1 & Sec $\mathbf{2 - 2}$ & \multicolumn{1}{c}{ Sec 3-3 } & \multicolumn{1}{c}{ Sec 4-4 } & \multicolumn{1}{c}{ Sec 5-5 } \\
\cline { 3 - 7 } & & $\mathbf{0 ~} \mathbf{~}$ & $\mathbf{6 , 6} \mathbf{~ m}$ & $\mathbf{1 3 , 6} \mathbf{~ m}$ & $\mathbf{2 0 , 6} \mathbf{~ m}$ & $\mathbf{2 5} \mathbf{~ m}$ \\
\hline \multirow{2}{*}{ DL } & balok pracetak & 0 & 269,36 & 465,52 & 569,53 & 587,73 \\
\hline DL & slab & 0 & 71,61 & 123,76 & 151,41 & 156,25 \\
\hline ADL & track + ballast & 0 & 129,79 & 224,32 & 274,43 & 283,20 \\
\hline DL & diafragma + deck slab & 0 & 30,51 & 52,73 & 64,51 & 66,57 \\
\hline LL & Kereta & 0 & 239,17 & 434,80 & 558,00 & 572,80 \\
\hline \multicolumn{2}{l}{ Total (DL+LL) } & 0 & 740,45 & 1301,12 & 1617,88 & 1666,56 \\
\hline
\end{tabular}

Tabel 8 Nilai Gaya dalam Geser Jembatan Kereta Api (dalam ton)

\begin{tabular}{llrrrrc}
\hline \multirow{2}{*}{ Tipe } & \multirow{2}{*}{ Beban } & Sec 1-1 & Sec $\mathbf{2 - 2}$ & Sec 3-3 & Sec 4-4 & Sec 5-5 \\
\cline { 3 - 7 } & & $\mathbf{0 ~} \mathbf{m}$ & $\mathbf{6 , 6} \mathbf{~ m}$ & $\mathbf{1 3 , 6} \mathbf{~ m}$ & $\mathbf{2 0 , 6} \mathbf{~ m}$ & $\mathbf{2 5} \mathbf{~ m}$ \\
\hline \multirow{2}{*}{ DL } & balok pracetak & 47,02 & 34,61 & 21,44 & 8,28 & 0 \\
\hline DL & slab & 12,50 & 9,20 & 5,70 & 2,20 & 0 \\
\hline ADL & track + ballast & 22,66 & 16,68 & 10,33 & 3,99 & 0 \\
\hline DL & diafragma + deck slab & 5,33 & 3,92 & 2,43 & 0,94 & 0 \\
\hline LL & Kereta & 46,90 & 39,49 & 31,65 & 23,81 & 18,78 \\
\hline \multicolumn{2}{l}{ Total (DL+LL) } & 134,40 & 103,89 & 71,55 & 39,21 & 18,78 \\
\hline
\end{tabular}

\section{Perhitungan Gaya Prategang Awal dan Kehilangan Gaya Prategang}

Nilai perhitungan gaya prategang awal dan kehilangan gaya prategang dapat diperlihatkan seperti dibawah ini.

Perhitungan tegangan awal:

Kondisi awal (transfer) di tengah bentang

serat atas, $\quad \sigma$ top $=\quad \mathrm{Pi} / \mathrm{Ac}-\mathrm{Pi} . \mathrm{e} / \mathrm{Wa}+\mathrm{Mbs} / \mathrm{Wa}$

$=\quad-19,2 \quad \mathrm{~kg} / \mathrm{cm}^{2}$

serat bawah, $\sigma$ bot $=\quad \mathrm{Pi} / \mathrm{Ac}+\mathrm{Pi} . \mathrm{e} / \mathrm{Wa}-\mathrm{Mbs} / \mathrm{Wa}$

$\mathrm{Pi}=2086,68$ ton

$=\quad 347,67 \quad \mathrm{~kg} / \mathrm{cm}^{2}$ 
Result:

$\begin{array}{lll}\mathrm{Pi}= & 1471,22 & \text { ton } \\ \mathrm{Pi}= & 1471,22 & \text { ton }\end{array}$

Kondisi layan di tengah bentang

$\begin{array}{lllrr}\text { serat atas, } \sigma \text { top }= & \text { Pe/Acp-(Pe.e-Mbp)/Wap }+\mathrm{Mbh} / \mathrm{Wac} & = & 325,94 & \mathrm{~kg} / \mathrm{cm}^{2} \\ & & \mathrm{Pe}= & 410,20 & \text { ton } \\ \text { serat bawah, obot }= & \text { Pe/Acp }+(\mathrm{Pe} . \mathrm{e}-\mathrm{Mbp}) / \mathrm{Wbp}-\mathrm{Mbh} / \mathrm{Wbc} & = & -42,97 & \mathrm{~kg} / \mathrm{cm}^{2} \\ & & \mathrm{Pe}= & 978,87 & \text { ton } \\ & \text { Result: } & \mathrm{Pe}= & 978,87 & \text { ton }\end{array}$

Kehilangan gaya prategang (satuan gaya dalam $\mathrm{kg}$, satuan jarak dalam m): Nilai jacking forces yang diambil adalah $75 \%$ dari Ultimate Tensile Stress. Sehingga perhitungan nya adalah sebagai berikut (Gambar 6):

Po (Jacking Force) $=75 \%$ x $0.987 \mathrm{~cm}^{2}$ x $19000 \mathrm{~kg} / \mathrm{cm}^{2}=14064,75 \mathrm{~kg}$

a. Gesekan

14064,75

11753,78

b. Slip Angkur

14064,75

12386,61

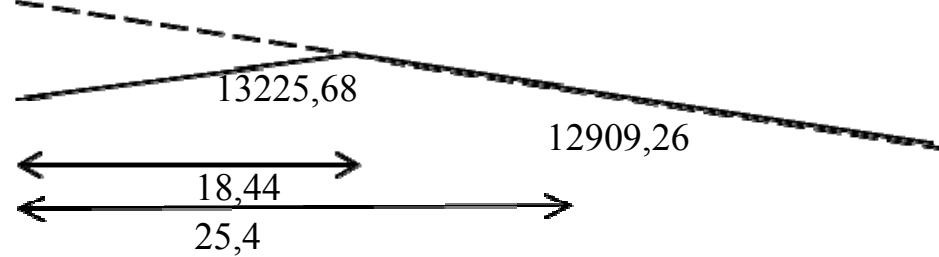

11753,78

c. Perpendekan Elastis

14064,75

12386,61

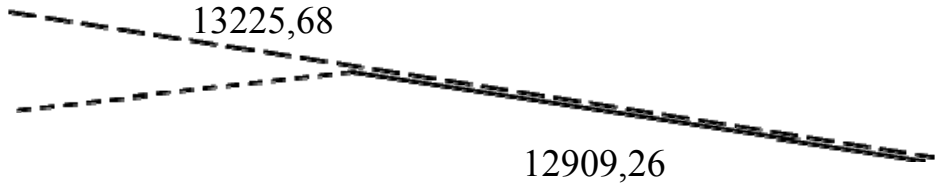

d. Kehilangan Prategang Jangka Panjang

14064,75

12386,61
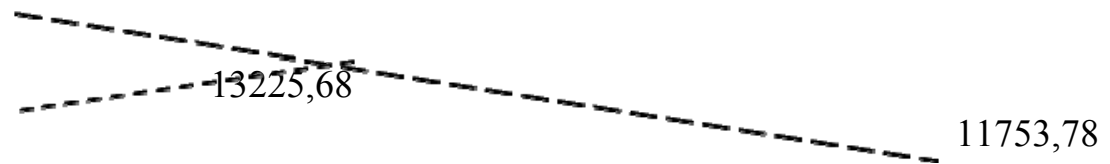

12765,42

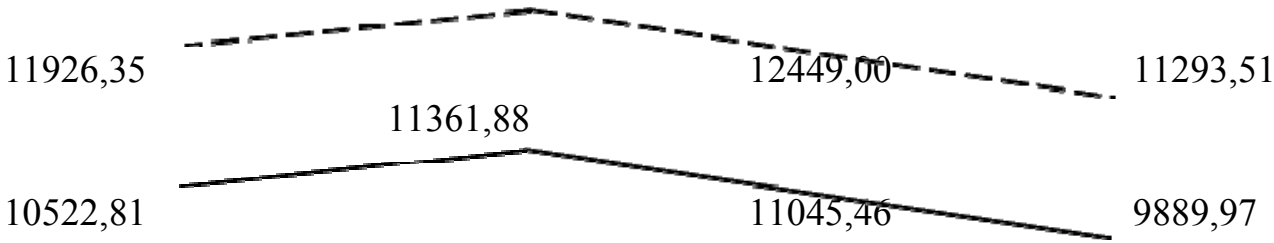

Gambar 6 Skema Kehilangan Gaya Prategang (satuan dalam kg) 
Dari hasil perhitungan kehilangan gaya prategang di atas, dapat dihitung besar nilai gaya prategang pada saat jacking forces, kondisi awal, dan kondisi masa layan (Tabel 9).

Tabel 9 Gaya Prategang

\begin{tabular}{rcccccc}
\hline Jacking force $=$ & 88 strand & $\mathrm{x}$ & 14064,75 & $=1237698,0$ & $\mathrm{~kg}$ \\
\hline Initial $=$ & 88 strand & $\mathrm{x}$ & 12909,26 & $=$ & 1136015,2 & $\mathrm{~kg}$ \\
\hline service $=$ & 88 strand & $\mathrm{x}$ & 11045,46 & $=$ & 972000,2 & $\mathrm{~kg}$ \\
\hline
\end{tabular}

\section{Tegangan pada Kondisi Awal}

Tegangan yang terjadi pada kondisi awal dari fungsi jembatan jalan raya dan kereta api seperti ditunjukkan pada Tabel 10 dan 11di bawah ini.

Tabel 10 Nilai Tegangan Kondisi Awal Jembatan Jalan Raya

\begin{tabular}{lrrrrr}
\hline \multicolumn{1}{c}{ Description } & Sec 1-1 & Sec 2-2 & Sec 3-3 & Sec 4-4 & Sec 5-5 \\
\hline $\mathrm{x}(\mathrm{m})$ & 0,00 & 6,60 & 13,60 & 20,60 & 25,00 \\
\hline Momen DL (ton.m) & 0,00 & 269,36 & 465,52 & 569,53 & 587,73 \\
\hline $\mathrm{Pi}($ ton) & 1136,02 & 1136,02 & 1136,02 & 1136,02 & 1136,02 \\
\hline $\mathrm{e}(\mathrm{m})$ & $-0,02$ & 0,36 & 0,65 & 0,80 & 0,82 \\
\hline Pi.e (ton.m) & 22,72 & $-408,87$ & $-738,24$ & $-908,60$ & $-931,32$ \\
\hline Momen net. (ton.m) & 22,72 & $-139,51$ & $-272,72$ & $-339,08$ & $-343,58$ \\
\hline $\mathrm{Pi} / \mathrm{A}\left(\mathrm{kg} / \mathrm{cm}^{2}\right)$ & 150,97 & 150,97 & 150,97 & 150,97 & 150,97 \\
\hline $\mathrm{M} / \mathrm{Wa}\left(\mathrm{kg} / \mathrm{cm}^{2}\right)$ & 5,97 & $-36,67$ & $-71,68$ & $-89,12$ & $-9,03$ \\
\hline $\mathrm{M} / \mathrm{Wb}\left(\mathrm{kg} / \mathrm{cm}^{2}\right)$ & $-5,55$ & 34,10 & 66,66 & 82,88 & 83,99 \\
\hline Serat atas $(\sigma \mathrm{t})$ & 156,94 & 114,30 & 79,29 & 61,85 & 141,94 \\
\hline Serat bawah $(\sigma \mathrm{b})$ & 145,42 & 185,07 & 217,63 & 233,85 & 234,96 \\
\hline
\end{tabular}

Tabel 11 Nilai Tegangan Kondisi Awal Jembatan Kereta Api

\begin{tabular}{lrrrrr}
\hline \multicolumn{1}{c}{ Description } & Sec 1-1 & Sec 2-2 & Sec 3-3 & Sec 4-4 & Sec 5-5 \\
\hline $\mathrm{x}(\mathrm{m})$ & 0,00 & 6,60 & 13,60 & 20,60 & 25,00 \\
\hline Momen DL (ton.m) & 0,00 & 269,36 & 465,52 & 569,53 & 587,73 \\
\hline $\mathrm{Pi}($ ton$)$ & 1136,02 & 1136,02 & 1136,02 & 1136,02 & 1136,02 \\
\hline $\mathrm{e}(\mathrm{m})$ & $-0,02$ & 0,36 & 0,65 & 0,80 & 0,82 \\
\hline Pi.e (ton.m) & 22,72 & $-408,97$ & $-738,41$ & $-908,81$ & $-931,53$ \\
\hline Momen net. (ton.m) & 22,72 & $-139,60$ & $-272,89$ & $-339,28$ & $-343,80$ \\
\hline $\mathrm{Pi} / \mathrm{A}\left(\mathrm{kg} / \mathrm{cm}^{2}\right)$ & 151,01 & 151,01 & 151,01 & 151,01 & 151,01 \\
\hline $\mathrm{M} / \mathrm{Wa}\left(\mathrm{kg} / \mathrm{cm}^{2}\right)$ & 5,97 & $-36,69$ & $-71,72$ & $-89,17$ & $-90,36$ \\
\hline $\mathrm{M} / \mathrm{Wb}\left(\mathrm{kg} / \mathrm{cm}^{2}\right)$ & $-5,55$ & 34,12 & 66,70 & 82,93 & 84,04 \\
\hline Serat atas $(\sigma \mathrm{t})$ & 156,98 & 114,31 & 79,29 & 61,83 & 60,65 \\
\hline Serat bawah $(\sigma b)$ & 145,45 & 185,13 & 217,71 & 233,94 & 235,04 \\
\hline
\end{tabular}




\section{Tegangan pada Kondisi Layan}

Tegangan yang terjadi pada kondisi layan dari fungsi jembatan jalan raya dan kereta api seperti ditunjukkan pada Tabel 12 dan 13 di bawah ini.

Tabel 12 Nilai Tegangan Kondisi Layan Jembatan Jalan Raya

\begin{tabular}{lrrrrr}
\hline \multicolumn{1}{c}{ Description } & Sec 1-1 & Sec 2-2 & Sec 3-3 & Sec 4-4 & Sec 5-5 \\
\hline x $(\mathrm{m})$ & 0,00 & 6,60 & 13,60 & 20,60 & 25,00 \\
\hline Momen DL (ton.m) & 0,00 & 400,14 & 691,53 & 846,03 & 873,08 \\
\hline Pi (ton) & 972,00 & 972,00 & 972,00 & 972,00 & 972,00 \\
\hline e (m) & $-0,02$ & 0,36 & 0,65 & 0,80 & 0,82 \\
\hline Pi.e (ton.m) & 19,43 & $-349,83$ & $-631,63$ & $-777,39$ & $-796,83$ \\
\hline Momen ... M1 (ton.m) & 19,43 & 50,31 & 59,90 & 68,64 & 76,25 \\
\hline Momen ... M2 (ton.m) & 0,00 & 762,38 & 1460,12 & 1957,83 & 2256,13 \\
\hline Pi / A $\left(\mathrm{kg} / \mathrm{cm}^{2}\right)$ & 129,17 & 129,17 & 129,17 & 129,17 & 129,17 \\
\hline M1 / Wa $\left(\mathrm{kg} / \mathrm{cm}^{2}\right)$ & 5,11 & 13,22 & 15,74 & 18,04 & 20,04 \\
\hline M1 / Wb $\left(\mathrm{kg} / \mathrm{cm}^{2}\right)$ & $-4,75$ & $-12,30$ & $-14,64$ & $-16,78$ & $-18,64$ \\
\hline M2 / Wa $\left(\mathrm{kg} / \mathrm{cm}^{2}\right)$ & 0,00 & 130,97 & 250,84 & 336,34 & 387,59 \\
\hline M2 / Wb $\left(\mathrm{kg} / \mathrm{cm}^{2}\right)$ & 0,00 & $-152,96$ & $-292,95$ & $-392,81$ & $-452,66$ \\
\hline Serat atas $(\sigma t)$ & 134,28 & 273,36 & 395,75 & 483,55 & 536,80 \\
\hline Serat bawah $(\sigma b)$ & 124,42 & $-36,09$ & $-178,43$ & $-280,42$ & $-342,13$ \\
\hline
\end{tabular}

Tabel 13 Nilai Tegangan Kondisi Layan Jembatan Kereta Api

\begin{tabular}{|c|c|c|c|c|c|}
\hline Description & Sec 1-1 & Sec 2-2 & Sec $3-3$ & Sec 4-4 & Sec 5-5 \\
\hline $\mathrm{x}(\mathrm{m})$ & 0,00 & 6,60 & 13,60 & 20,60 & 25,00 \\
\hline Momen DL (ton.m) & 0,00 & 371,48 & 642,01 & 785,44 & 810,55 \\
\hline Pi (ton) & 972,00 & 972,00 & 972,00 & 972,00 & 972,00 \\
\hline $\mathrm{e}(\mathrm{m})$ & $-0,02$ & 0,36 & 0,65 & 0,80 & 0,82 \\
\hline Pi.e (ton.m) & 19,44 & $-349,92$ & $-631,80$ & $-777,60$ & $-797,04$ \\
\hline Momen M1 (ton.m) & 19,44 & 21,56 & 10,21 & 7,84 & 13,51 \\
\hline Momen M2 (ton.m) & 0,00 & 368,97 & 659,12 & 832,43 & 856,00 \\
\hline $\mathrm{Pi} / \mathrm{A}\left(\mathrm{kg} / \mathrm{cm}^{2}\right)$ & 129,20 & 129,20 & 129,20 & 129,20 & 129,20 \\
\hline $\mathrm{M} 1 / \mathrm{Wa}\left(\mathrm{kg} / \mathrm{cm}^{2}\right)$ & 5,11 & 5,67 & 2,68 & 2,06 & 3,55 \\
\hline $\mathrm{M} 1 / \mathrm{Wb}\left(\mathrm{kg} / \mathrm{cm}^{2}\right)$ & $-4,75$ & $-5,27$ & $-2,50$ & $-1,92$ & $-3,30$ \\
\hline $\mathrm{M} 2 / \mathrm{Wa}^{\prime}\left(\mathrm{kg} / \mathrm{cm}^{2}\right)$ & 0,00 & 63,39 & 113,23 & 143,01 & 147,06 \\
\hline $\mathrm{M} 2 / \mathrm{Wb}^{\prime}\left(\mathrm{kg} / \mathrm{cm}^{2}\right)$ & 0,00 & $-74,03$ & $-132,24$ & $-167,02$ & $-171,75$ \\
\hline Serat atas $(\sigma \mathrm{t})$ & 134,31 & 198,26 & 245,12 & 274,27 & 279,81 \\
\hline Serat bawah $(\sigma b)$ & 124,45 & 49,91 & $-5,53$ & $-39,73$ & $-45,84$ \\
\hline
\end{tabular}

\section{Perbandingan Tegangan Jembatan Jalan Raya dan Kereta Api}

Dari hasil Tabel 12 dan 13, dapat diambil kesimpulan nilai tegangan maksimum yang terjadi pada gelagar I untuk fungsi jembatan jalan raya dan jembatan kereta api sebagai berikut (Tabel 14). 
Tabel 14 Perbandingan Tegangan Jembatan Jalan Raya dan Kereta Api

\begin{tabular}{lccccc}
\hline \multicolumn{1}{c}{$\begin{array}{c}\text { Batas Tegangan } \\
\left(\mathbf{k g} / \mathbf{c m}^{2}\right)\end{array}$} & \multicolumn{2}{c}{ Jalan Raya } & \multicolumn{2}{c}{ Kereta Api } \\
\cline { 2 - 6 } & & $\begin{array}{c}\text { Tegangan } \\
\left(\mathbf{k g} / \mathbf{c m}^{2}\right)\end{array}$ & Cek & $\begin{array}{c}\text { Tegangan } \\
\left(\mathbf{k g} / \mathbf{c m}^{2}\right)\end{array}$ & Cek \\
\hline Kondisi Awal: & & & & \\
\hline Serat atas & -19.22 & 60.65 & OK & 60.65 & OK \\
\hline Serat bawah & 347.67 & 235.04 & OK & 235.04 & OK \\
\hline Kondisi Layan: & & & & & OK \\
\hline Serat atas & 325.94 & 215.76 & OK & 279.81 & NOT OK \\
\hline Serat bawah & -42.97 & 28.96 & OK & -45.84 & \\
\hline
\end{tabular}

\section{PENUTUP}

Dari hasil perhitungan antara jembatan gelagar I bentang $50 \mathrm{~m}$, dapat di ambil kesimpulan bahwa untuk tinggi gelagar $210 \mathrm{~cm}$ pada jembatan kereta api, tegangan pada serat bawah tidak mencukupi batas tegangan yang di ijinkan. Dari hasil ini dapat diidentifikasikan bahwa dengan tinggi gelagar $210 \mathrm{~cm}$ pada jembatan kereta api belum mampu menahan beban yang ada pada jembatan kereta api.

\section{DAFTAR PUSTAKA}

Badan Standardisasi Nasional. (2004). Perencanaan Struktur Beton untuk Jembatan, SNI T-12-2004. Jakarta: Badan Standardisasi Nasional.

Badan Standardisasi Nasional. (2005). Perencanaan Pembebanan untuk Jembatan, SNI T- 02-2005. Jakarta: Badan Standardisasi Nasional.

Badan Standarisasi Nasional. (2004). Pelaksaan Pekerjaan Beton untuk Jembatan dan Jalan Pedoman T-07-2005. Jakarta: Badan Standarisasi Nasional.

Railway Technical Institute. (2004). Design Standard Railway Structure for Concrete Structure. 